\title{
High Resolution Lake Sediments from New Zea- land - a Record of Late Holocene Storm History, Vegetation Change and Landscape Response
}

New Zealand, isolated in the South Pacific Ocean $2000 \mathrm{~km}$ southeast of Australia, was the last major land mass to be inhabited by humans. Polynesians are believed to have arrived less than 1000 years ago, while European settlement and extensive conversion of forest to pastoral land began only 150 years ago (Page and Trustrum 1999).

A maritime climate characterised by high intensity rainstorms, and strongly influenced by El Niño-Southern Oscillation, and a tectonically active, erodible landscape free of human impacts for much of the Holocene, makes New Zealand an ideal location to seek records of past climate variability and environmental change. The recent and dramatic human impact on the landscape also provides an opportunity to identify landscape response to land use/vegetation change.

A research programme is in progress to investigate the relative roles climatic, tectonic, and anthropogenic factors play in high rates of erosion and terrestrial and marine sedimentation, by providing late Quaternary paleoenvironmental histories of the East Coast region North Island, and by understanding the role of tectonism and long-term patterns of sediment fluxes on landscape evolution. Research by our team began in 1988 with a study of erosion and sedimentation responses to land use/vegetation change and climatic variability within a small catchment at Lake Tutira in northern Hawke's Bay (Fig. 1). This is essentially a closed system where sediment sources and sink are closely coupled. In 1992, the research transferred to the larger, more complex Waipaoa River basin, near Gisborne (Fig. 1). Here the depositional response to climatic, tectonic and anthropogenic forcing is buffered by transport lags, temporary storage, and the general diffusion of the magnitudes and frequencies of sediment contributions from the spatially variable distribution of erosion processes within the various tributaries (Trustrum et al. 1999, Gomez et al. 1999 and Hicks et al. 2000). More recently, the

Murrumbidgee, continued from page 16

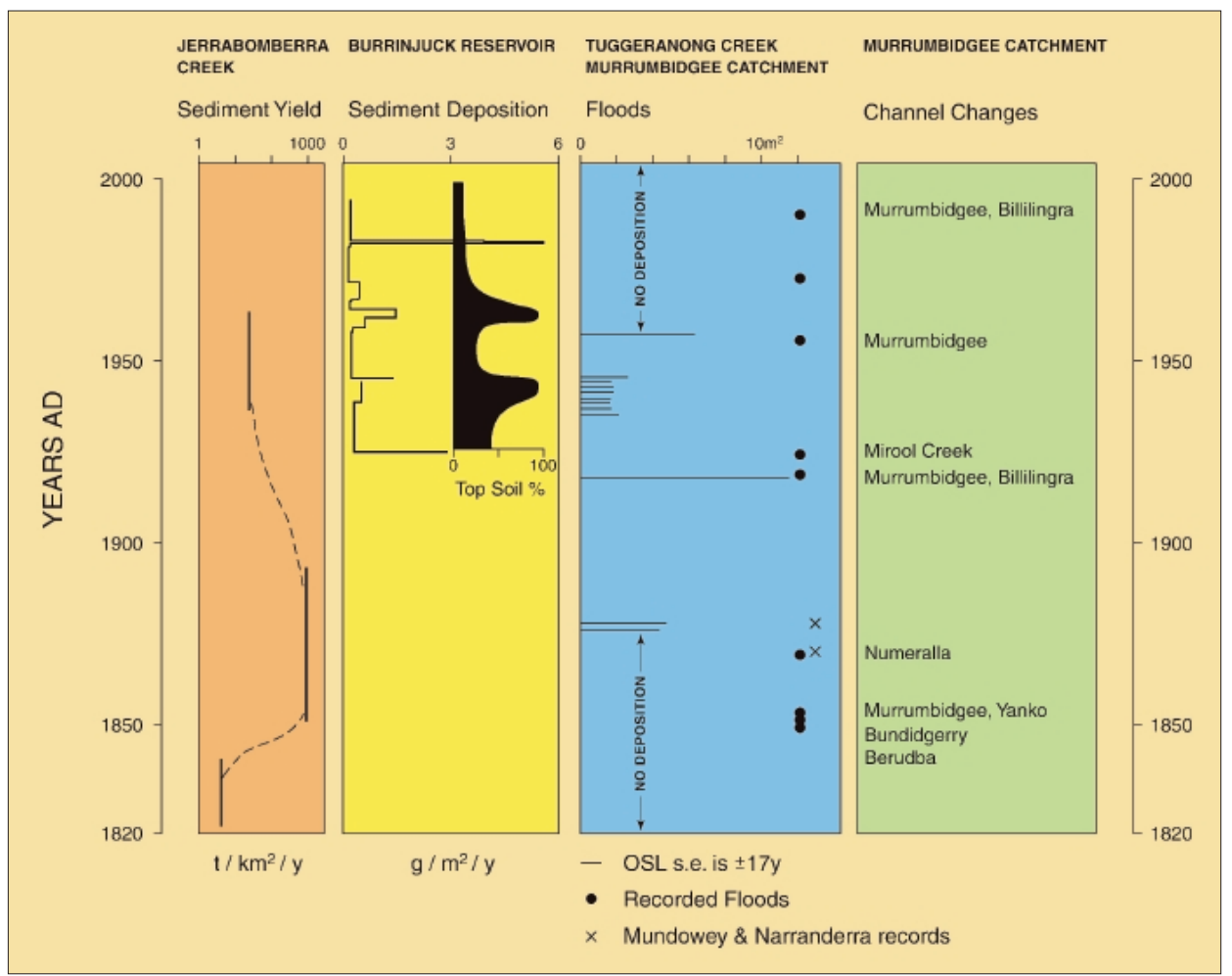

Figure 1: Evidence for sediment yield, sediment deposition, flood frequencies and channel changes at sites within the Murrumbidgee River catchment, Australia.

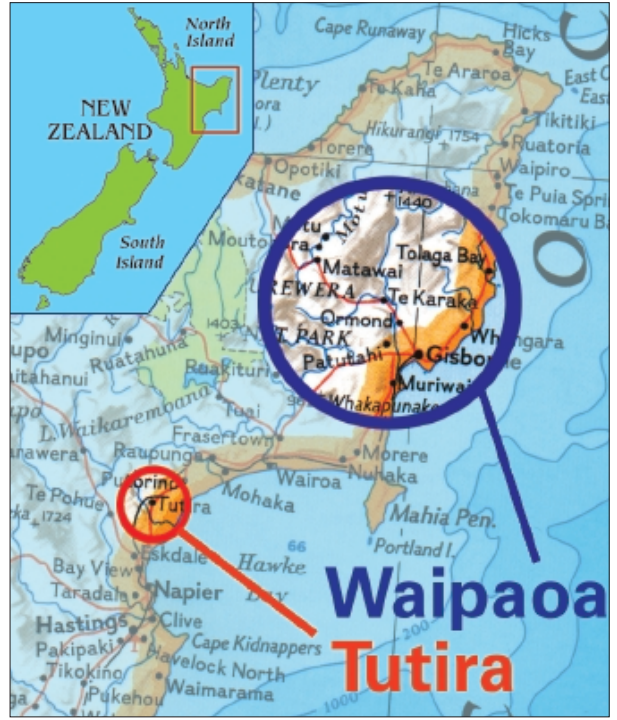

Figure 1: Location of Lake Tutira and Waipaoa catchment.

emphasis has shifted to examining sediment archives from coupled land and ocean environments in the Waipaoa sedimentary system. Key questions for sustainable land use and management of these landscapes are: at what rate, over what time scale, and to what level will the landscape respond and recover from naturally and anthropogenically induced changes? (Page et al. 2000).

\section{Land Use and ClimateVariability in the Tutira Catchment}

Lake Tutira is one of a number of landslide-dammed lakes on the east coast of the North Island (Fig. 2). It is highly sensitive to environmental changes, both natural and human-induced, in the surrounding landslide-prone $32 \mathrm{~km}^{2}$ catchment. The steep, dissected hills, underlain by soft siltstones and sandstones, have been mantled by a number of tephras that provide valuable time lines of landscape

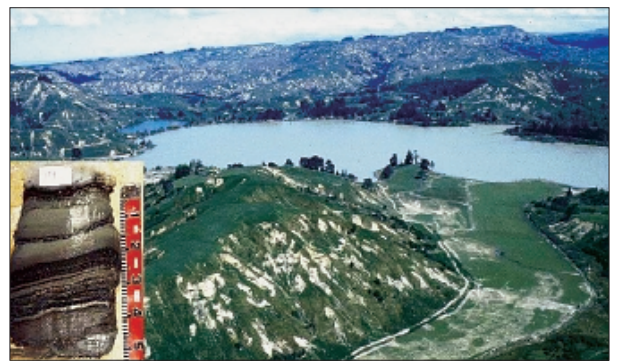

Figure 2: Lake Tutira and surrounding landslide-prone steeplands following Cyclone Bola. (Photo: N.A. Trustrum, September 1988). Inset shows laminated lake sediments - light grey layers are the products of individual storm events, dark layers are organic deposits produced by annual decomposition of weed and algae associated with eutrophication. 


\section{New Zealand, continued from page 17}

change. These catchment characteristics, and the morphometry and thermal stratification of the lake, are conducive to the formation and preservation of laminated sediments, including the erosion products of individual storms (Fig. 2).

Our studies at Tutira began with the construction of a sediment budget for a major storm - Cyclone Bola. This storm, with a rainfall of $753 \mathrm{~mm}$ in 4 days, occurred in March 1988, and is the largest on record. Sediment was generated at a rate of $48720 \mathrm{t} / \mathrm{km}^{2}, 90 \%$ of which was derived from landslides. Fifty-six percent of this sediment then entered the lake (Page et al. 1994a). Analysis of the lake sediments show that high magnitude events produced disproportionately large amounts of sediment in comparison with low magnitude events, with Cyclone Bola and the next largest storms on record responsible for more than half the storm-generated sediment since European arrival.

Correlation of storm-generated sediment layers with storm history has identified the threshold for the generation of sediment, and the relationship between sediment thickness and storm rainfall. However, the relationship is not straightforward and is affected by changes in the threshold for landsliding or "event resistance", where the magnitude and/or frequency of earlier storms reduces the available sediment (Page et al. 1994b).

Human impacts in the catchment began only 500 years ago with Polynesian arrival, and consisted of repeated burning of the indigenous forest and replacement by fern and scrub (Wilmshurst 1997). European conversion to pasture began in the late 1870's. This recent but dramatic human impact is also recorded in the lake sediments. While the sedimentation rate increased by $\sim 60 \%$ under fern/scrub, following conversion to pas-

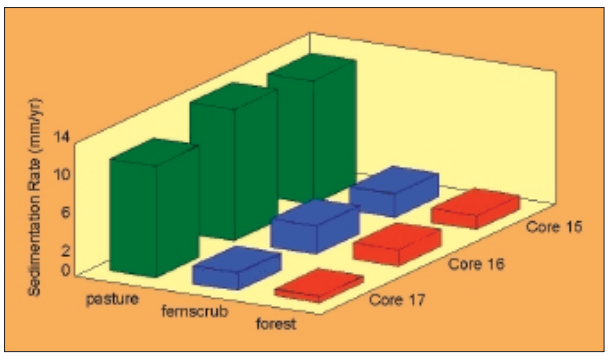

Figure 3: Sedimentation rates in Lake Tutira under forest, fern/scrub, and pasture (after Page and Trustrum 1997). ture the sedimentation rate increased by an order of magnitude (Fig. 3) (Page and Trustrum 1997). These high erosion and sedimentation rates have led to concerns about the sustainability of pastoral farming on these landscapes.

The lake sediments also contain a high resolution record of climate variability and landscape response for much of the Holocene that is free of human impacts. A 6500 year history of the magnitude and frequency of paleostorms is preserved in the sediment. To date, the chronology of storms for the last c. 2250 years has been established from a c.6m core (Eden and Page 1998). In the pre-European record there are 340 storms layers, with an average storm return interval of $\sim 6$ years. However, the frequency of these storm varies. Clusters of sediment layers identify six major periods of increased erosion, five of which are related to increased storm frequency. During these periods the average return interval of storms is 1-3 years, whereas in the less stormy periods intervals are $7-13$ years (Fig. 4).

The dates of the storm periods are 2175-2155, 2090-1855, 1455-1435, 1085935, and 375-355 cal. yr B.P. Most of these periods correspond to warm climate intervals previously identified from New Zealand and other Southern Hemisphere paleoclimatic evidence. A majority of the storms recorded in the European derived sediment are associated with La Niña phases of ENSO, and we are currently investigating the relationship between the magnitude and frequency of storms and ENSO for the 2250 year period, and correlating this record with other proxy records of paleoclimate to identify long-term climate variability for this region of New Zealand.

\section{Ongoing Research of Land-Marine Inter- actions in the Waipaoa Sedimentary System}

Research in the $\sim 2200 \mathrm{~km}^{2}$ source and $\sim 900 \mathrm{~km}^{2}$ sink Waipaoa sedimentary system is focussed on using sediment budgets and high resolution sediment cores from floodplains, terraces and the marine depocentre to improve our ability to investigate how the magnitude and frequency of the erosional and nutrient response varies with land use/vegetation, climatic regime, and tectonic controls. Our intention is to improve understanding of significant global change issues, such as the influ-

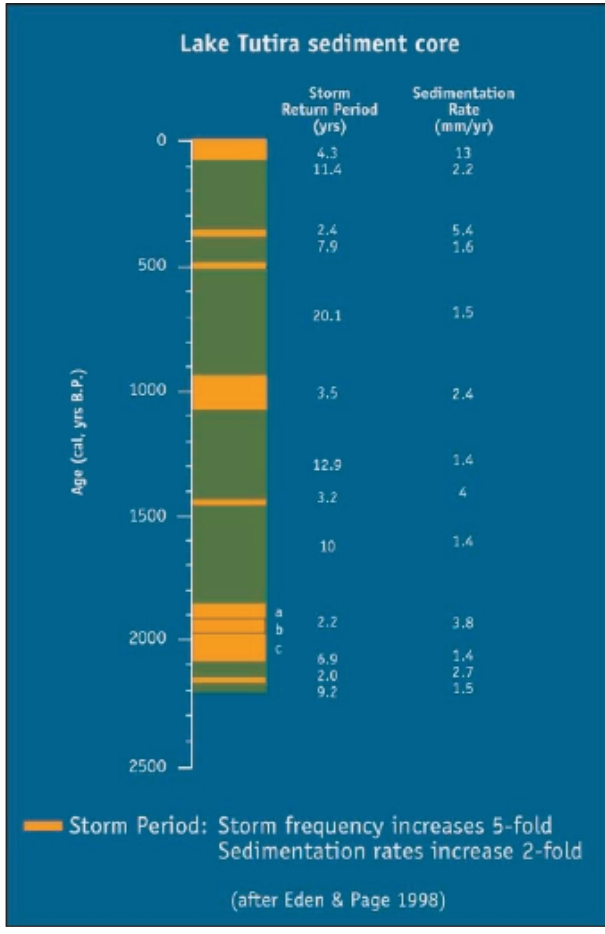

Figure 4: Variation in storm frequency derived from a c.2250 year long sediment record from Lake Tutira (after Eden and Page 1998).

ence of sea temperature changes on terrestrial rainfall, by determining the extent to which climate variability and tectonic forcing control land-marine sedimentary systems.

Key collaborators include scientists from Landcare Research, National Institute of Water and Atmospheric Research (NIWA-Oceanographic and Freshwater), Geological and Nuclear Sciences (GNS-Earth Deformation), Indiana State University and Gisborne District Council. The Waipaoa sedimentary system has been chosen as a focus site for the US NSF MARGINS Source-to-Sink programme. Paleoenvironmental studies here will primarily focus on Holocene shifts of climate, and anthropogenic disturbances since about 500 cal years BP, where accompanying changes in vegetation profoundly modified the pattern and rate of erosion and the sediment-nutrient fluxes. Research activities for the MARGINS programme will begin in July 2001.

\section{Mike Page and Noel Trustrum}

Landcare Research, Palmerston North, New Zealand pagem@landcare.cri.nz

trustrumn@landcare .cri.nz

For full references please consult www.pagesigbp.org/products/newsletters/ref2003.html 